\title{
Investigating Anthropometric Measurements and Nutritional intake Changes after Intermittent Fasting Accompanied by Exercise in Adult Women
}

\author{
Mona S. EI Kutry \\ Home Economics Dept, Faculty of Specific Education, \\ Ain Shams Univ, Cairo Egypt
}

\section{Introduction:}

Obesity is a big problem that has a great effect on health and production. Approximately 2.1billion people in global suffer from obesity. And over 3 million of world populations every year die from obesity World Population Review (2020). In Egypt, the rate of obesity raised to $32 \%$ in adults, while obesity in females represented $41.1 \%$ in 2016 according to World Data Atlas (2019). Except for age, family history, and physical inactivity, obesity is one of the major etiological risk factors for type two diabetes with $80 \%$ of diabetic patients being obese (chadt, et al., 2018 ; Forouhi, et al., 2014) .Increased adiposity and weight gain are established risk factors for psoriasis, a chronic inflammatory skin disease (Jensen et al., 2014).

Generally, many reasons caused obesity e.g., low physical activity; over nutrition accompanied; metabolism diseases and gene variants may predispose to obesity (Albuquerque, et al., 2015 and Ruperez, et al., 2014). Obesity was defined as BMI $\geq 28 \mathrm{~kg} / \mathrm{m}^{2}$ and/or WC in male $\geq 90 \mathrm{~cm}$ while in female $\geq 85$ cm (SCOCSECMA, 2011 and WHO,2018). Furthermore, a meta-analysis of 239 prospective studies demonstrated that the risk of death from all-cause starts to increase when the body mass index (BMI) enters the overweight range $(\geq 25$ $\mathrm{kg} / \mathrm{m}^{2}$ ) (Global BMI Mortality Collaboration, 2016). Conicity index (CI) is considering an accuracy tool to evaluate the distribution of fat mass. Despite BMI can't distinguish fat mass and lean mass clearly and its prediction is prone to be disturbed by the difference of samples in adipose distribution (Lei ,et al.,2006; Zhang, et al., 2018). Intermittent fasting (IF) means calorie restriction low-calorie diets - also referred to as low-energy diets, for one or several days a week, or every day as the extension of the overnight fast. Ramadan fasting is a unique model of prolonged intermittent fasting and re-feeding (Cheah, et. al., 1990; Zubrzycki, et al., 2018). 
Studies in animals and humans showed that many of the health benefits of intermittent fasting are not only the result of reduced free-radical production or weight loss (Panda, 2016, Francesco et al., 2018; Longo and Mattson, 2014) but also intermittent fasting bring out increases in stress resistance and suppresses inflammation, evolutionarily conserved, adaptive cellular responses that are incorporated between and within organs in a manner that improves glucose regulation (Panda, 2016; Patterson \&Sears, 2017).

Many studies showed that daily caloric restriction improves many cardiometabolic risk factors in non-obese humans (Weiss, et al., 2017; Goodpaster, et al., 2010; Ruggenenti.et al., 2017). Also, six short-term studies involving obese or overweight adults showed that intermittent fasting was as effective for weight loss as standard diets (Norris, et al., 2005).

Finally, our study aims to establish training and educating unit for intermittent fasting across social media groups and to evaluate the effect of implementing intermittent fasting plus exercise for six weeks on the anthropometric and nutritional parameters in adult women.

\section{Subjects and methods:}

Subjects: One hundred females were randomly chosen from social media groups of Facebook and What's App at the age from (26 to 49 years old) based in Riyadh -Saudi Arabia and have multi-nationality of Arab countries (27\%Jordan, 25\%Syria, 17\%Egypt, 13\% Saudi Arabia, 8\%Yemen, and15\% Philistine). Prepared the training unit, collected data, and participates were from February to May 2018.

\section{Training Unit of Intermittent Fasting}

Design the training unit included lectures presented through Skype application for fifteen days $(45 \mathrm{~h}$.) the training unit aims to provide each participant with the following information.

1- The principles and benefits of intermittent fasting.

2- The basics of balance and a healthy diet.

3- Forbidden foods (high in fat - sodium - fried - artificial sweeteners.)

4- Antioxidant in food and herbs

5- Food zero calories and allowed through fasting.

6- Allowance of food and drinking during fasting time. 
7- How to calculate the calories inside your food and hidden carioles in fast food.

8- The body measurement and suitable time of weight.

9- Body shape and differences between the muscles and fat.

10- The importance of exercise activity during intermittent fasting.

11- Exchange system in nutrition.

At the end of the lectures period, 83 women only accept to participate in the diet, exercise system, and blood analysis for six weeks, 17 women didn't approve to share their measurements and blood analysis.

\section{Intermittent Fasting Experiment}

Anthropometric Measurements: Correct methods for taking anthropometric measurements were explained to all participants to assist the examiner in obtaining correct measurements.

Females were weighed by lightly dressed and barefoot before started the fasting and followed ones per week. Height was measured to the nearest millimeter and weight to the nearest $0.1 \mathrm{Kg}$ using standardized electronic digital scales in the nearest medical centers or/ pharmacy. The measurements were used to calculate the body mass index (BMI) by dividing weight in $(\mathrm{kg})$ by height in meters square $\left(\mathrm{kg} / \mathrm{m}^{2}\right)$ were calculated according to World Health Organization (WHO, 2018). Waist circumference (WC) was measured using a measuring tape to the nearest $0.1 \mathrm{~cm}$ at the midpoint between the highest point of the iliac crest and the lowest part of the costal margin. Hip circumference (HC) was measured using a measuring tape to the nearest $0.1 \mathrm{~cm}$ at the highest point of the iliac crest at minimal expiration. The waist-hip ratio (WHR) is the dimensionless ratio of the circumference of the waist to that of the hips. This is calculated as waist measurement divided by hip measurement $(\mathrm{WC} \div \mathrm{HC}$ ) according to WHO, (2018). Conicity index (CI) $=\mathrm{WC} /(0.109 \times$ square root of weight/height), where WC and height were measured in meters and weight was measured in kilograms (Rato; Índice, 2017).

Evaluation of Nutrition Intake: 24-h recall was used to determine calorie intake (carbohydrate, protein, fat) for three unfollowing days, and repeated every week during the experimental period (six weeks). Participants entered a 6weeks of weight loss program aimed at reducing body weight by $10 \%$.To determine the level of 500 to $700 \mathrm{kcal}$ were subtracted from direct calories. During intermittent fasting regimen, all meals were consumed within a strictly defined window of time, fasting (eating only for several hours each day and fasting $12 \mathrm{~h}$. allowed water ad libitum for the remainder of the day. Each week of fasting system followed by a day free. 


\section{Exercise Program}

The exercise program included: aerobics, running, swimming, and walking followed for $30 \mathrm{~min}$ at least three times per week, using Gym/YouTube channels. Daily physical activity level (measured in the total minutes of steps) also, using the Application (Samsung/Apple Health - Android/ IOS). Participates shared the screenshot of their Mobiles to assess the exercise time spent. Each exercise session began with 5 min of warm-up and ended with 5 min of cool-down. Participates shared the screenshot of their Mobiles to assess the exercise timing.

Questionnaire: The questionnaire was administrated to females included name, age, healthy states, (pregnancy or lactation), allergy of some food, drug intake or dietary supplement, smoking.

Oxidizer Test: Applicator the test to assess the participants according to three basic groups:

(fast oxidizers, slow oxidizers, and balanced oxidizers). This test has been adapted and translated to a woman who participated in the program. The test consisted of 46 multiplication questions, sent to women by Email/ What's App, every participates answer the questions (the number of A, B and $\mathrm{C}$ answers you have circled chosen the best answer) then sending to the researcher to calculates the divided the participates according to the Oxidizer Test ( Michaels, Van, 2009).

Blood analysis: Blood analyses were done before and after the diet system in Al Borg Medical Laboratories, Riyadh, Saudi Arabia. Hemoglobin (Hb) as described by the International Committee for Standardization in Hematology (1967) .Red blood cell (RBC) and white blood cell (WBC) counts were determined as described by Natt and Herrick, (1952).

\section{2- Statistical analysis:}

The quantitative data showed as mean, and standard deviation SD, while qualitative data were expressed as frequency and percent. Data has been collected and entered into the computer using SPSS (Statistical Package for Social Science) program for statistical analysis. A significant P-value was considered when $P$ is less than or equal $0.05(\mathrm{p} \leq 0.05)$ Paired $t$ - test was used to show the significant differences before and after the intermittent fasting (SPSS, 2010). 
Table (1) Screening characteristics of women completing the study at baseline of intermittent fasting $(n=83)$.

\begin{tabular}{|l|l|l|}
\hline \multicolumn{2}{|l|}{ Variables } & Values \\
\hline Age( $\mathrm{y})$ Mean $\pm \mathrm{SD}$ & $38.9 \pm 6.2$ \\
\hline & Weight $(\mathrm{Kg})$ Mean $\pm \mathrm{SD}$ & $84.60 \pm 15.2$ \\
\cline { 2 - 3 } & Height $(\mathrm{m})$ Mean $\pm \mathrm{SD}$ & $1.60 \pm 0.1$ \\
\cline { 2 - 3 } & BMI $\left(\mathrm{Kg} / \mathrm{M}^{2}\right)$ Mean $\pm \mathrm{SD}$ & $31.3 \pm 4.6$ \\
\hline \multirow{2}{*}{} & $\%$ of subject with fast oxidizers & Zero (n) \\
\cline { 2 - 3 } & $\%$ of subject with slow oxidizers & 70 (n) $84 \%$ \\
\cline { 2 - 3 } & $\%$ of subject with balanced oxidizers & $13(\mathrm{n}) 16 \%$ \\
\hline
\end{tabular}

\section{Results and discussion}

Table (1) screening characteristics of women completing the study at baseline the fasting $(\mathrm{n}=83)$. The results indicated the women participants at intermittent fasting were aged (38.9 \pm 6.2 years), the mean weight was $(84.60 \pm$ $15.2 \mathrm{Kg})$, and the mean BMI was $\left(31.3 \pm 4.6 \mathrm{Kg} / \mathrm{m}^{2}\right)$. Also, the results in a table (1) revealed that a high percentage of $84 \%$ of women who participated in fasting have slow oxidizers and $16 \%$ of women with balanced oxidizers. The oxidizer test was developed to help determine metabolic type based on 45 questions, ranging from psychological behavior, physiological appearance, and general metabolic patterns or tendencies (Worthington, 2006). Michaels and Van, (2009) reported the theory goes that there are three metabolic types slow, neutral, and fast oxidizers. The slow oxidizer diet calls for a higher percentage of carbohydrates than protein or fat. The type of carbohydrates, fat, and protein you consume is as important as the ratio. Wolcott \& Fahey, (2002) propose that there are three general metabolic types: Protein types are fast oxidizers, carbohydrate types are slow oxidizers, and mixed types are mixed oxidizers .Noakes, (2005) have shown sedentary females displaying signs of the metabolic syndrome may benefit more from a moderate carbohydrate and higher protein intakes than had originally been advocated.

Table (2) presents a comparison between anthropometric measurements of subjects and health status before and after the fasting. The results indicated the 
women participated in an intermittent fasting were a high percentage of obese $\left(31.3 \pm 4.6 \mathrm{Kg} / \mathrm{m}^{2}\right)$. The obesity of grade $1(\mathrm{BMI}>30-35)$ was a high percentage of $37.3 \%$ in participants, while the low percentage was $4.8 \%$ for women who have obesity in grade 3. The obtained data agree with the international percentage of obesity, however, the WHO reported that $39 \%$ of adults aged 18 years and older were overweight or obese (WHO, 2018). In Egypt, the mean BMI of women, 2016 equals $31.7 \mathrm{Kg} / \mathrm{m}^{2}$ (GBD, 2017). The results indicated that about $92.72 \%$ of subjects have overweight and obese, and $85.5 \%$ of those having waist circumference $\geq 80(\mathrm{~cm})$ as well as, $77.1 \%$ of women had waist to hip ratio $\leq 0.85$, meanwhile $22.9 \%$ of women have a waist to hip ratio $\geq 0.85$ to interpret these results according to WHO (2018) who have a waist to hip ratio of over 0.85 may increase the risk of developing conditions that relate to being overweight, including heart disease and type 2 diabetes. The high waist circumference results indicated to obesity and metabolic disease, for the pattern of fat distribution showed a large influence on cardiometabolic risk (Amato, et al., 2013). Besides, abdominal obesity seems to predict the development of cardiovascular diseases better than overall obesity (Siren, et al., 2012; Lean, et al.,

1995).

This may be the case even if other measures of being overweight, such as body mass index (BMI) are in the normal range (WHO, 2018; Zwierzchowska et al., 2013; Mørkedal, et al., 2011; Hall, et al., 2012).

Table (2) represented that BMI significant $(p \leq 0.01)$ decrease of women after six weeks, followed IF plus exercise compared to women before fasting. Also, the results indicated the percentage of subjects has a healthy weight became highly raise after the fast ( $18.07 \%$ vs. $7.2 \%$ before fasting). BMI subgroups revealed the percentage of subjects after fasting has a highly decreased with obesity in grade 2 and grade $3(4.8 \%$, zero \% compared to $20.5 \%, 4.8 \%)$ before fasting, respectively.

Our results appeared the waist circumference significantly decreased $(\mathrm{P} \leq$ 0.01) of women after six weeks of fasting. The results of the waist circumference subgroups summarized, the subjects have the waist circumference ( $\geq 80 \mathrm{~cm}$.) decreased from $85.5 \%$ to $59.04 \%$ after six weeks of intermittent fasting plus exercise. Oliveira, et al., 2001 indicated that waist circumference is highly correlated with BMI $(\mathrm{r}=0.89, \mathrm{p}=0.001)$ in female adolescents. Correspondingly, waist circumference $(<80 \mathrm{~cm}$. $)$ was also improved and increased to $40.9 \%$ compared to $14.5 \%$ before fasting. Hip circumference general $(\mathrm{cm})$ was significantly $(\mathrm{P} \leq 0.01)$ lower for women after six weeks of IF plus exercise. Table (2) reported a waist-to-hip ratio $(>0.85)$ lower percentage for women after six weeks of IF plus exercise compared to 
before fasting ( $22.9 \%$ vs. $10.8 \%)$. Conversely, with waist-to-hip ratio $(<0.85)$. The conicity index improved significantly between women $(p<0.01)$ after the sixth week. So, CI is a useful and accurate tool to evaluate the distribution of fat mass. However, Fontela et al., (2017) study the conicity index, body mass index, and waist circumference as predictors of coronary artery disease. Consent, with Cortez, et al., 2010 reported the prevalence of obesity or overweight among diabetic patients was $84.6 \%$ and that the prevalence of abdominal obesity was $69.3 \%$.

Table (2) Comparison between anthropometric measurements of adult women before and after the intermittent fasting

\begin{tabular}{|c|c|c|c|c|}
\hline & Variables & $\begin{array}{c}\text { Before (First } \\
\text { week) } \\
\text { Mean } \pm \text { SD }\end{array}$ & $\begin{array}{c}\text { After (6 } \\
\text { weeks ) } \\
\text { Mean } \pm \text { SD }\end{array}$ & $\begin{array}{c}\text { P- } \\
\text { value }\end{array}$ \\
\hline 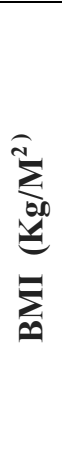 & $\begin{array}{c}\text { BMI }\left(\mathbf{K g} / \mathbf{M}^{2}\right) \text { Mean } \pm \text { SD } \\
\% \text { of subject with BMI }(18.5-250) \\
(\text { Healthy weight }) \\
\% \text { of subject with BMI } \geq 25-30 \\
\quad(\text { Over weight }) \\
\% \text { of subject with BMI } \geq 30-35 \\
\quad \text { (Obesity grade } 1) \\
\% \text { of subject with BMI } \geq 35-40 \\
\quad \text { (Obesity grade } 2) \\
\% \text { of subject with BMI } \geq 40 \\
\text { (Obesity grade } 3)\end{array}$ & $\begin{array}{c}31.3 \pm 4.6 \\
\mathrm{~N}=6 \\
7.2 \% \\
\mathrm{~N}=25 \\
30.12 \% \\
\mathrm{~N}=31 \\
37.3 \% \\
\mathrm{~N}=17 \\
20.5 \% \\
\mathrm{~N}=4 \\
4.8 \%\end{array}$ & $\begin{array}{c}29.22 \pm 3.9 * \\
\mathrm{~N}=15 \\
18.07 \% \\
\mathrm{~N}=29 \\
34.9 \% \\
\mathrm{~N}=35 \\
42.2 \% \\
\mathrm{~N}=4 \\
4.8 \% \\
\mathrm{~N}=\text { zero }\end{array}$ & 0.0014 \\
\hline \multirow{4}{*}{ 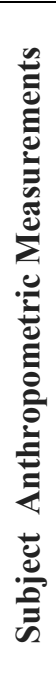 } & $\begin{array}{l}\quad \text { Waist Circumference }(\mathrm{cm}) \\
\text { Waist Circumference }(\mathrm{cm}) \text { subgroup } \\
\text { waist circumference } \geq 80(\mathrm{~cm}) \\
\text { with waist circumference } \leq 80(\mathrm{~cm})\end{array}$ & $\begin{array}{c}\mathbf{9 5 . 7} \pm \mathbf{1 3 . 7} \\
\mathrm{N}=71 \\
85.5 \% \\
\mathrm{~N}=12 \\
14.5 \%\end{array}$ & $\begin{array}{c}86.8 \pm 13.3^{*} \\
\mathrm{~N}=49 \\
59.01 \% \\
\mathrm{~N}=34 \\
40.9 \%\end{array}$ & 0.008 \\
\hline & Hip circumference general $(\mathrm{cm})$ & $117.01 \pm 11.0$ & $\begin{array}{c}112.7 \pm \\
10.5 *\end{array}$ & 0.0001 \\
\hline & $\begin{array}{l}\text { waist-to-hip ratio total } \\
\text { waist-to-hip ratio } \geq 0.85 \\
\text { with waist-to-hip ratio } \leq 0.85\end{array}$ & $\begin{array}{c}\mathbf{0 . 8 2} \pm \mathbf{0 . 1} \\
\mathrm{N}=19 \\
22.9 \% \\
\mathrm{~N}=6477.1 \%\end{array}$ & $\begin{array}{c}\mathbf{0 . 8} \pm \mathbf{0 . 0 7 *} \\
\mathrm{N}=9 \\
10.8 \% \\
\mathrm{~N}=74 \\
89.2 \% \\
\end{array}$ & 0.0003 \\
\hline & Conicity Index (CI) & $1.0 \pm 0.11$ & $0.2 \pm 0.0 *$ & 0.0001 \\
\hline
\end{tabular}

*Values in given at column which have * are mean significantly at $(\mathrm{P}<0.01)$

* represent between values before and after intermittent a significant change 
Dietary changes as a result of intermittent fasting for six weeks plus exercise in the adult women presented in table (3), the results show the calories intakes of women were significantly $(\mathrm{P} \leq 0.01)$ lower compared to before fasting as well as the value of chosen food raised. However, change the percent of food groups ( $70 \%: 412.75 \pm 90 \mathrm{~g}$ carbohydrate, $15 \%: 88.48 \pm 21 \mathrm{~g}$ protein, $15 \%: 39.3 \pm 9 \mathrm{~g}$ fat ) before fasting vs. (55\%: $231 \pm 22 \mathrm{~g}$ carbohydrate, $30 \%$ : $126.03 \pm 17 \mathrm{~g}$ protein, $15 \%: 28.0 \pm 12 \mathrm{~g}$ fat ) after fasting. Michaels, (2010) performed the diet system to fast oxidizers; require a high percentage of protein and fat than carbohydrates. Michaels, (2010) and Wolcott \& Fahey, (2002) recommended to consume a diet relative to their metabolic type of an individual which is considered to be appropriate and essential to providing them with the correct percentages of the macronutrients (carbohydrate, protein, and fat). Our finding agrees with Scholtens, et al., (2020) who reported the energy intake decreased by the sixth week when compared with baseline during the intermittent fasting for six weeks. The new systematic review of IF and weight loss indicated all 27 IF trials found a weight loss of $0.8 \%$ to $13.0 \%$ of baseline weight with no serious adverse events. Twelve studies comparing IF to calorie restriction found equivalent results (Welton. et al., 2020). Meanwhile Daniel, et al., (2020) revealed that the metabolic typing questionnaire does accurately reflect the real metabolic processes going on in the body and need further study is warranted in a larger sample, indifferent in populations of different ethnicity.

Our results associate the changes and improved significantly in body wt., BMI, and CI. These results in agreement with Armamento, et al., (2014) present the calorie intake restriction that causes weight loss, decrease fat tissue, and provides powerful protection against many chronic diseases. Heilbronn, et al., (2006) reported the prolonged calorie restriction by diet or by a combination of diet and exercise was successfully implemented as evidenced by reduced weight, fat mass, fasting serum insulin, and body core temperature. These results appear the intermittent fasting for six weeks revealed improvement at anthropometric measurements of subjects and decrease the calories intakes. Ooi, Pak (2019) supporting these results. 
Table (3) Dietary changes as a result of intermittent fasting for six weeks plus exercise in adult women

\begin{tabular}{|c|c|c|c|}
\hline Variables & $\begin{array}{c}\text { Before the fasting } \\
\text { Mean } \pm \text { SD * }\end{array}$ & $\begin{array}{c}\text { After sixth week } \\
\text { Mean } \pm \text { SD }\end{array}$ & P-value * \\
\hline $\begin{array}{c}\text { Calories (Kcal) } \\
\text { 24-h (kcal/day) }\end{array}$ & $2359.0 \pm 449.0$ & $1680.2 \pm 553.5 *$ & $(\mathrm{P} \leq 0.01)$ \\
\hline Carbohydrate (\%/g) & $412.75 \pm 90$ & $231 \pm 22^{*}$ & $(\mathrm{P} \leq 0.01)$ \\
\hline Protein (g) & $88.48 \pm 21$ & $126.03 \pm 17^{*}$ & $(\mathrm{P} \leq 0.01)$ \\
\hline Fat (g) & $39.3 \pm 9$ & $28.0 \pm 12^{*}$ & $(\mathrm{P} \leq 0.01)$ \\
\hline
\end{tabular}

* represent between values before and after intermittent a significant change

The results of figures ( 2 and 3 ) indicated the changes of body-weight for six weeks no significant difference during every week from the first to the sixth week. The observation the body weight decreased through week after week but not significant. Conversely, the changes of body-weight were significant $(p<0.01)$ before and after the sixth weeks. Meanwhile, wt. before was $(85.7 \pm 14.5 \mathrm{~kg}$. vs. after $77.5 \pm 12.6 \mathrm{~kg}$.). We can interpret these results as the IF plus exercise prevents the body-weight decline quickly but, the human body control in decline weight from muscles. Supported those results were by the waist circumference, BMI, and conicity index results. Da Luz, et al., (2015) reported the rapid weight loss has side effects and can't have beneficial clinical effects similar to slow weight lost and found that people, who follow severe calorie-restricted diets, will not have an eating disorder and will be able to maintain their lost weight. In contrast, found by Jazet, et al., 2008 have shown that rapid weight loss with high-calorie restriction could cause an improvement of clinical state in obese individuals.

\begin{tabular}{|c|c|c|}
\hline Variables & $\begin{array}{c}\text { Before the fasting } \\
\text { Mean } \pm \text { SD }\end{array}$ & $\begin{array}{l}\text { After sixth week } \\
\text { Mean } \pm \text { SD }\end{array}$ \\
\hline Hemoglobin (gm/dL) & $11.7 \pm 0.8$ & $12.0 \pm 0.9$ \\
\hline $\begin{array}{c}\text { Red blood } \\
\text { cell }(\mathrm{mil} / \mu \mathrm{L})\end{array}$ & $\begin{array}{c}4.1 \pm \\
0.4\end{array}$ & $4.0 \pm 0.4$ \\
\hline $\begin{array}{l}\text { white blood } \\
\text { cell }\left(10^{3} / \mathrm{uL}\right)\end{array}$ & $\begin{array}{c}6.9 \pm \\
1.3\end{array}$ & $7.1 \pm 1.4$ \\
\hline
\end{tabular}

No differences between groups for any parameter (dependent samples t-test).

The results in the table (4) indicated the hemoglobin levels, RBC, and WBC count were not significantly different before and after the fasting. However, intermittent fasting decreases significantly in body weight, BMI, waist circumference, hip circumference general, waist-to-hip ratio, and CI before and after the fasting is safe for blood picture. Agreement with (Ooi, Pak 2019) showed that short-term intermittent fasting (35days) for two days per week and ad libitum eating for the other five days didn't affect hemoglobin levels. As well as, Wojciak,(2014) reported that the mean concentrations of iron in hair and serum, and ferritin levels did not change after the starvation period (one- and two-day food restrictions (every 8 days for 48 days) of women, compared to the beginning of the experiment. 


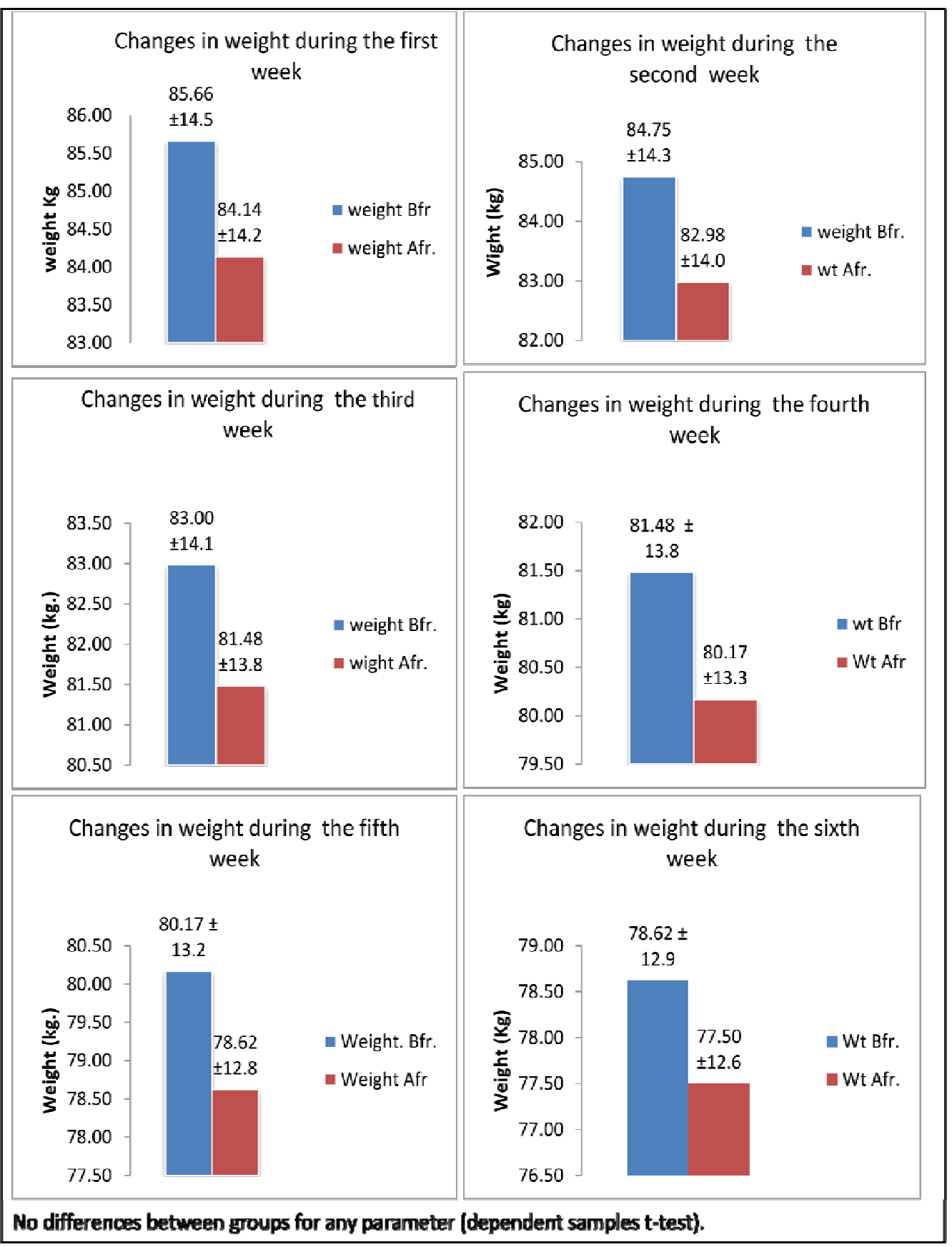

Figure (1) Weekly weight changes during six weeks of intermittent fasting plus exercise in adult women 


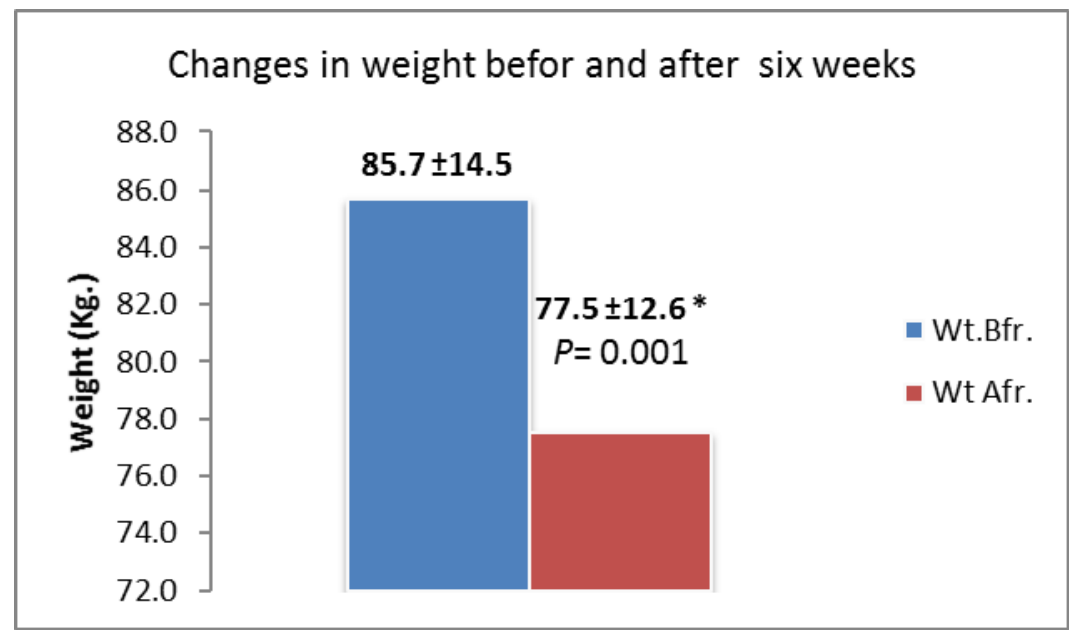

Figure (2) Changes of Body-weight for six weeks

\section{Conclusion:}

The intermittent fasting through some hours 10-14 h. /day combined with exercise activity (1/2hour 3 times/ per week) for 6 weeks improved the body shape, BMI, anthropometric measurements, healthy statues for adult women. 


\section{Reference}

- Albuquerque D, Stice E, Rodriguez-Lopez R, Manco L,Nobrega C. (2015). Current review of genetics of human obesity:from molecular mechanisms to an evolutionary perspective.Mol Genet Genomics; 290: 1191-1221.

- Amato C, Guarnotta V, Giordano C. (2013). Body composition assessment for the definition of cardiometabolic risk. J Endocrinol Investig. 36:537-43.

- Armamento-Villareal R, Aguirre L, Napoli N, Shah K, Hilton T, Sinacore DR, Qualls C, Villareal DT. (2014). Changes in thigh muscle volume predict bone mineral density response to lifestyle therapy in frail, obese older adults. Osteoporos Int. ,25(2):551-8.

- Chadt A, Scherneck S, joost HG, Al-Hasani H. (2018). Molecular links between obesity and diabetes: diabesity, In: Endotext (Internet). De Groot Lj, Chrousos G, Dungan K, et al. (eds). South Dartmouth (MA). MDText.com, Inc., 2000

- Cheah SH, Ch'ng SL, Husain R \& Duncan MT (1990). Effects of fasting during Ramadan on urinary excretion in Malaysian Muslims. $\mathrm{Br}$ J Nutr 63, 329-337.

- Cortez-Dias N, Martins S, Belo A, Fiuza M. (2010). Prevalência, tratamento econtrolo da diabetes mellitus e dos factores de risco associados nos cuidados de saúde primários em Portugal. Rev Port Cardiol. 29:509---37.

- Da Luz F, Hay P, Gibson A, Touyz S, Swinbourne J, Roekenes J .(2015) Does severe dietary energy restriction increase binge eating in overweight or obese individuals? A systematic review. Obes Rev. 16(8):652-65.

- Daniel C, David E, Sam H, Andrea B. (2020). Physiological analysis of the metabolic typing diet in professional rugby union players-Waikato Institute of Technology Vol 35, No. 2.

- Fontela C, Winkelmann R, Viecili N. (2017) .Estudo do índice de conicidade, índice de massa corporal e circunferência abdominal como preditores de doenc, a arterial coronariana. Rev Port Cardiol.; 36:357--64. 
- Forouhi G, Wareham J.(2014). Epidemiology of diabetes. Medicine (Abingdon) 42: 698-702.

- Francesco A, Germanio C, Bernier M, Cabo R. (2018). A time to fast. Science 362: 770-5.

- GBD (2017). Risk Factor Collaborators. Global, regional, and national comparative risk assessment of 84 behavioral, environmental and occupational, and metabolic risks or clusters of risks for 195 countries and territories, 1990-2017: a systematic analysis for the Global Burden of Disease Study. The Lancet. 8;392:1923-94

- Global BMI Mortality Collaboration, (2016) Body-mass index and allcause mortality: individual-participant-data metaanalysis of 239 prospective studies in four continents. Lancet

- Goodpaster H, Delany P, Otto D Kuller L, Vockley J, South-Paul E, Thomas B, Brown J, McTigue K, Hames C, Lang W, Jakicic M. (2010). Effects of diet and physical activity interventions on weight loss and cardiometabolic risk factors in severely obese adults: a randomized trial. JAMA 304: 1795-1802.

- Hall D, Heymsfield B, Kemnitz W, Klein S, Schoeller A, Speakman R. (2012). Energy balance and its components: implications for body weight regulation. The American Journal of Clinical Nutrition, 95(4), 989-994.

- Heilbronn K, De Jonge L, Frisard I, De Lany P, Larson-Meyer E, Rood J, Nguyen T, Martin K, Volaufova J, Most M, Greenway L, Smith R, Deutsch A, Williamson A, Ravussin E. (2006). Effect of 6-month calorie restriction on biomarkers of longevity, metabolic adaptation, and oxidative stress in overweight individuals: a randomized controlled trial. JAMA. 2006 Apr 5;295(13):1539-48.

- International Committee for Standardization in Haematology (ICSH) (1967). Brit J Haemat. 13 (Suppl.): 71.

- Jazet M, Schaart G, Gastaldelli A, Ferrannini E, Hesselink K, Schrauwen P. (2008). Loss of $50 \%$ of excess weight using a very low energy diet improves insulin-stimulated glucose disposal and skeletal muscle insulin signalling in obese insulin-treated type 2 diabetic patients. Diabetologia. 51(2) 
- Jensen P, Zachariae C, Christensen R, Geiker R, Schaadt K, Stender S, Hansen R, Astrup A, Skov L. (2014). Effect of weight loss on the cardiovascular risk profile of obese patients with psoriasis. Acta Derm Venereol 94: 691-694.

- Lean E, Han S, Morrison E. (1995). Waist circumference as a measure for indicating need for weight management. BMJ. 311:158-61.

- Lei S, Liu Y, Chen D, Deng Y, Lv H, Jian X, Xu H, Tan J, Yang J, Wang B, Xiao M, Sun X, Jiang C, Guo F. (2006) .Relationship of total body fatness and five anthropometric indices in Chinese aged 20-40 years: different effects of age and gender. Eur J Clin Nutr. 60, 511-8.

- Longo D, Mattson P. (2014). Fasting: molecular mechanisms and clinical applications. Cell Metab , 19: 181-92.

- Michaels J, Van M. (2009). Master Your Metabolism: The 3 Diet Secrets to Naturally Balancing Your Hormones for a Hot and Healthy Body! Kindle Edition- Crown Publish groups.

- Michaels J. (2010). Winning by losing .Harpercollins publishers New York .second edition.Pp 70-90.

- Mørkedal B, Romundstad R, Vatten J. (2011). Informativeness of indices of blood pressure, obesity and serum lipids in relation to ischaemic heart disease mortality: the HUNT-II study". European Journal of Epidemiology. 26 (6): 457-461.

- Natt M, Herrick C. (1952). A new blood count diluent for counting erythrocytes and leukocytes of the chicken PoultSci 31: 735-738.

- Noakes M. (2005). The CSIRO Total Wellbeing Diet. Australia: Penguin Books.

- Norris L, Zhang X, Avenell A. (2005) .Long-term nonpharmacologic weight loss interventions for adults with type-2 diabetes. Cochrane Database Syst Rev , (2):

- Oliveira L, Veiga V, Sichieri R. (2001). Anthropome tric markers for cardiovascular disease risk factors among overweight adolescents. Nutrition Research. 21:1335-1345.

- Ooi L, Pak C. (2019). Short-term Intermittent Fasting for Weight Loss: A Case Report. Cureus, 11(4). 
- Panda S. (2016) .Circadian physiology of metabolism. Science. 354: 1008-15.

- Patterson RE, Sears DD. (2017). Metabolic effects of intermittent fasting. Annu Rev Nutr . 37: 371-393.

- Rato Q, Índice De Conicidade. (2017). Uma medida antropométrica a avaliar. Rev Port Cardiol.

- Ruggenenti P, Abbate M, Ruggiero B, Rota S, Trillini M, Aparicio C, Parvanova A (2017).Renal and systemic effects of calorie restriction in patients with type-2diabetes with abdominal obesity: a randomized controlled trial. Diabetes , 66: 75-86.

- Ruperez I, Gil A, Aguilera M. (2014). Genetics of oxidative stress in obesity. Int J Mol Sci , 15: 3118-3144.

- Scholtens E, Krebs D, Corley T, Hall M. (2020). Intermittent fasting 5:2 diet: What is the macronutrient and micronutrient intake and composition? Clinical Nutrition, Volume 1, Issue 3, 123-133.

- Siren R, Eriksson G, Vanhanen H. (2012). Waist circumference a good indicator of future risk for type 2 diabetes and cardiovascular disease. BMC Public Health. 12:631.

- SPSS (2010). Statistical Package for Social Science releases 6, spss. Inc. Chicago.

- SCOCSECMA: Sub-Committee of Obesity of Chinese Society of Endocrinology of Chinese Medical Association.) (2011). Chinese expert consensus on prevention and treatment of Obesity in adults. Chin J Endocrinol Metab. 27, 711-17.

- Weiss P, Jordan C, Frese M, Albert G, Villareal T. (2017). Effects of weight loss on lean mass, strength, bone, and aerobic capacity. Med Sci Sports Exerc 2017; 49: 206-217.

- _Welton S, Minty R, 'Driscoll T, Kelly L. (2020). Intermittent fasting and weight loss: Systematic review- Canadian family physician Medecin de famille canadien 66(2):117-125

- Wilcott M, Fahey T. (2002). The Metabolic Typing Diet. New York: Broadway Books. 
- Wojciak W. (2014). Effect of short-term food restriction on iron metabolism, relative well-being and depression symptoms in healthy women. Eating and weight disorders: EWD, 19(3), 321-327.From. https://doi.org/10.1007/s40519-013-0091-2

- World Data Atlas (2019). From https://dataworldatlas.com/Knoema, free application that provides quick access to country statistics.

- WHO (2018) World Health Organization . Obesity and Overweight Fact Sheet (updated 16.02.2018).From http://www.who.int/en/newsroom/fact-sheets/detail/obesity-andoverweight (12.11.2018).

- World Population Review (2020). World Population by Country-Egypt population From. http://worldpopulationreview.com/countries/mostobese-countries.

- Worthington V. (2006). Metabolic Typing: Slow-Oxidizers, FastOxidizers. Retrieved: 2nd

- Zhang Y, Zeng Q, Li X, Zhu P, Huang F.(2018). Application of Conicity Index adjusted total body fat in young adults-a novel method to assess metabolic diseases risk. Sci Rep 8.

- Zubrzycki,A, Cierpka-kmiec K, Kmiec Z, Wronska A. (2018), the role of low-calorie diets and intermittent fasting in the treatment of obesity and type-2 diabetes- journal of physiology and pharmacology , 69, 5, 663-683

- Zwierzchowska A, Grabara M, Danuta Palica D, Zając A. (2013) . BMI and BAI as Markers of Obesity in a Caucasian Population . Obesity Facts; 6:507-511. 


\section{Abstract \\ Investigating Anthropometric Measurements and Nutritional intake Changes after Intermittent Fasting Accompanied by Exercise in Adult Women}

Obesity is a big problem that has a great effect on health and production. Approximately 2.1billion people in global suffer from obesity. As well as the female obesity in Egypt were $41.1 \%$ in 2016. Subjects and methods: One hundred females were randomly chosen from social media groups of Facebook and What's App at the age from (26 to 49 years old) have multi-nationality of Arab countries. Design the training unit included lectures presented through Skype application for fifteen days $(45 \mathrm{~h}$.) the training unit aims to provide each participant with the knowledge of Intermittent Fasting (IF) principles and healthy diet after, the finish of the training unit 83 females accepted to participate in the IF plus exercise activity for 6 weeks. Results: The obesity of grade $1(\mathrm{BMI}>30-35)$ was a high percentage of $37.3 \%$ in participants, while the low percentage was $4.8 \%$ for women who have obesity in grade 3 . Results indicated that about $92.72 \%$ of subjects have overweight and obese, and $85.5 \%$ of those having waist circumference $\geq 80(\mathrm{~cm})$. BMI was significantly $(\mathrm{p} \leq 0.01)$ decreased in women after six weeks followed IF plus exercise compared to women before fasting. The calorie intakes and conicity index of women were significantly $(\mathrm{P} \leq 0.01)$ lower compared to before fasting. The hemoglobin levels, RBC, and WBC counts were not significantly different before and after fasting. Conclusion: The intermittent fasting through some hours $12 \mathrm{~h} . /$ day combined with exercise activity (1/2 hour 3 times/ per week) for 6 weeks improved the body shape, BMI, anthropometric measurements, healthy statues for adult women.

Keywords: Intermittent Fasting, Anthropometric Measurements, Nutritional Intake, Training Unit. 


\section{ملخص البحث}

دراسه التغيرات في القياسات الجسميه والماخوذ الغذائي بعد الصيام المتقطع المرافق للتمرينات الرياضيه في السيدات البالغات

تعتبر السمنه مشكله كبيره لها اثار عظيمه علي الصحه والانتاجيه ـ تقريبا اثثان مليون فرد عالميا

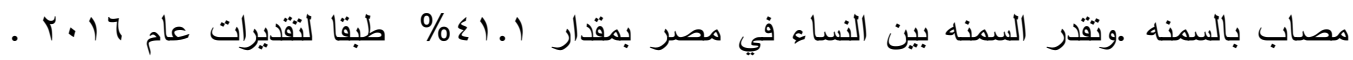

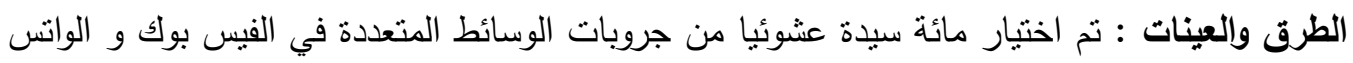

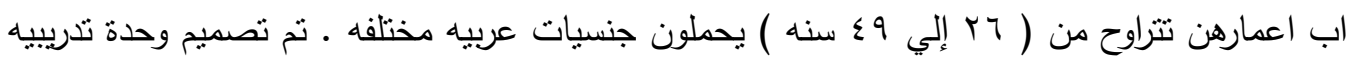

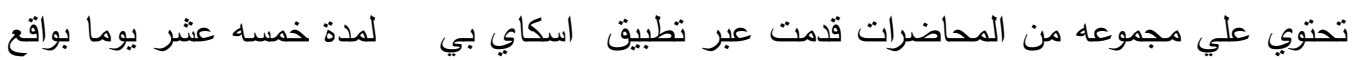

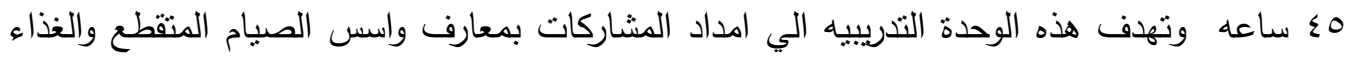

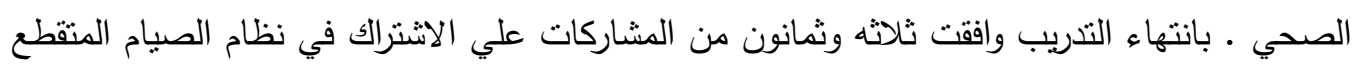

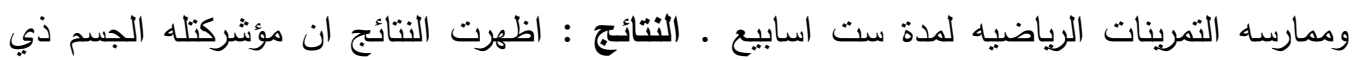
الدرجه الاولي 35-30> كانت بنسبه مرتفعه ب \% 37.3 في المشاركات ـ والسمنه من الدرجه الثالثه

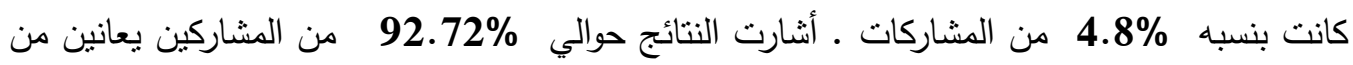

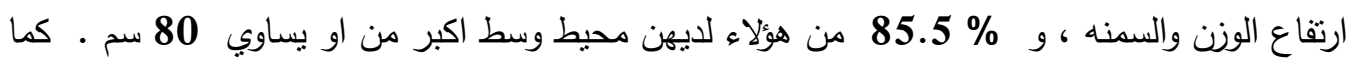
ان مؤشر كتله الجسم انخفض معنوية عند مستوي دلاله ( P

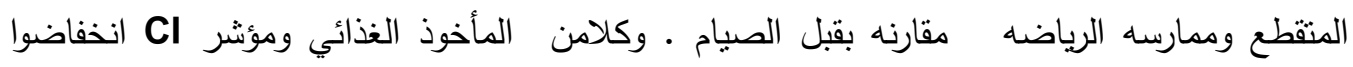

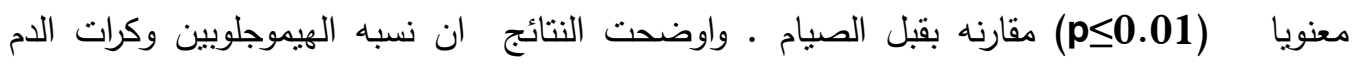

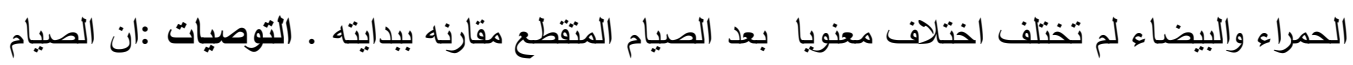

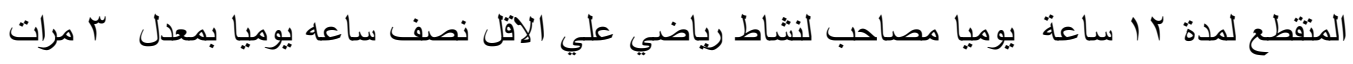
اسبوعيا لمدة 7 اسابيع يحسن شكل ومؤشر كتله الجسم والقياسات الجسميه والحاله الصحيه للنساء

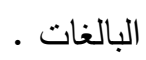

الكلمات المفتاحية :

الصيام المنقطع ، المقاييس الجسميه ، الحاله الغذائيه ، وحدة تدريب. 